\title{
Current Investment Strategies for Private Individuals as Small Investors in Times of Low Interest Rates
}

Ing. Martin A. Moser, MA. MSc

István Széchenyi Doctoral School

University of Sopron

Erzsébet street 9, H-9400 Sopron, Hungary

Phone: +43 (0) 6648475687

Email: martin.arnold.moser@phd.uni-sopron.hu

martin.arnold.moser@gmail.com

\section{ABSTRACT}

Hungary

\begin{abstract}
Money plays an important role, both on a social and an individual level. Secure forms of investment hardly bring any interest. Also, state financial support has changed and will continue to do so in the future. A constructive, forward-looking approach to private finances and long-term wealth accumulation are therefore becoming increasingly important. Finding the right system at the right time is a challenge that small private investors have to face continuously. On the internet, in magazines or television programs, investors will find a flood of information. The fact that unlimited amounts of data can be accessed, often creates more confusion than perspective. This applies particularly to the investment business. Based on a literature review, this article provides an overview of current forms of investment for small private investors and uses qualitative research via problem-centered interviews to critically compare their advantages and disadvantages in times of low interest rates.
\end{abstract}

\section{KEYWORDS: financial investments, interest rates, investment strategies}

\section{JEL CODES: G10, G11, G21}

\section{Introduction}

The financial world and with it the investment strategies have changed massively in recent years. Globalization and digitization (keyword industry 4.0) have reached every corner of the financial world. We can observe how old principles are becoming less important and trust in financial institutions is decreasing. Since interest rates have vanished to a negligible level or have disappeared completely and shares are to take this place, small private investors are now coming into contact with an opportunity-oriented asset class that may not have originally planned to do so (Hintze,
2019, p. IX). The banking industry is under increasing pressure. Due to the 2007/2008 financial crisis and the behavior of many banks before the crisis, it has lost a lot of its public reputation (Gulden, 2018, p. V). Aftermath of the stock market crashes in 2000 and 2007/2008 and general attitudes of citizens lead to distrust of people who are more concerned with money matters. They are often seen as superficial and morally questionable in the eyes of others. Dealing with money fails, because this topic brings little social confirmation. (Rieksmeier, 2010, p. 16).

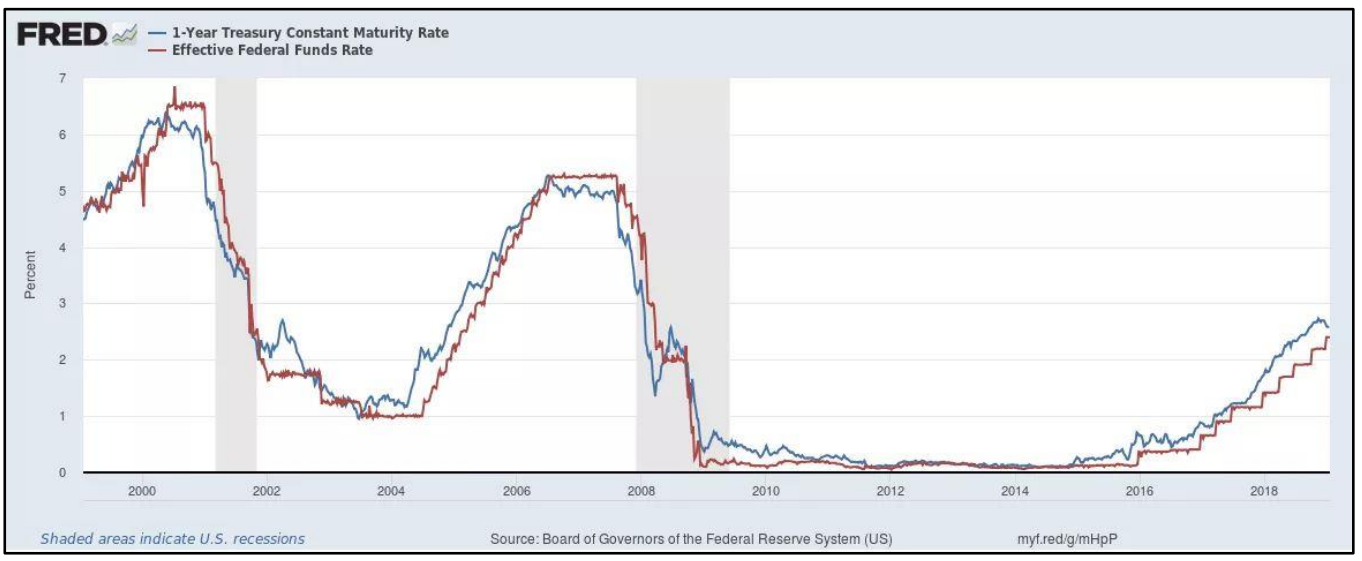

Figure 1: Low Interest Rate Environment 
E-ISSN: 2469-6501

VOL: 6 , ISSUE: 4

April/2020

DOI: $10.33642 / f j b a s s . v 6 n 4 p 4$

CPER

https://iibassnet.com/

(C) Center for Promoting Education and Research (CPER) USA

WWW.cpernet.org

Due to the current low-interest-rate environment and the need for private provision for old age, the question of the right investment strategies has become significantly more complex, far-reaching and also important. The success of private individual investment strategies is also determined by financial knowledge. A lack of financial knowledge for example about the relationship between risk and return in the population can lead to wrong decisions in wealth accumulation and old-age provision (Fischer \& Wagner, 2017, p. 1).

\section{Definition of terms}

The term "investment strategy" is not only to be understood as the investment of the money freely available today. Rather, private provision and also company pensions are becoming increasingly important due to the falling level of pensions. The low-interest-rate policy announced after the bankruptcy of the US investment bank Lehman Brothers and the purchase programs for bonds, particularly by the European Central Bank, continue to shape investors' investment strategies worldwide (Lindmayer \& Dietz, 2020, p. V).
The term "private individuals as small investors" is referring to customers of financial institutions, who can be divided into different segments based on various characteristics. First, corporate customers can be distinguished from private customers. For private individuals, the focus is on their own and private interests as well as securing the personal situation. Private customers are natural persons and not legal entities. Natural persons and associations of natural persons (e.g. married couples) belong to the group of private individuals (Gulden, 2018, pp. 12-13).

\section{Problem statement}

State financial support, especially pensions, is constantly changing. The level of the statutory pension is steadily falling and is already insufficient to maintain the standard of living in retirement (Müller, 2020, p. 1). Even if there is currently no interest and consequently no compound interest effect, it is important to start saving early. The later the retirement planning is started, the more needs to be put aside to be able to close later pension gaps (Hintze, 2019, p. 2).

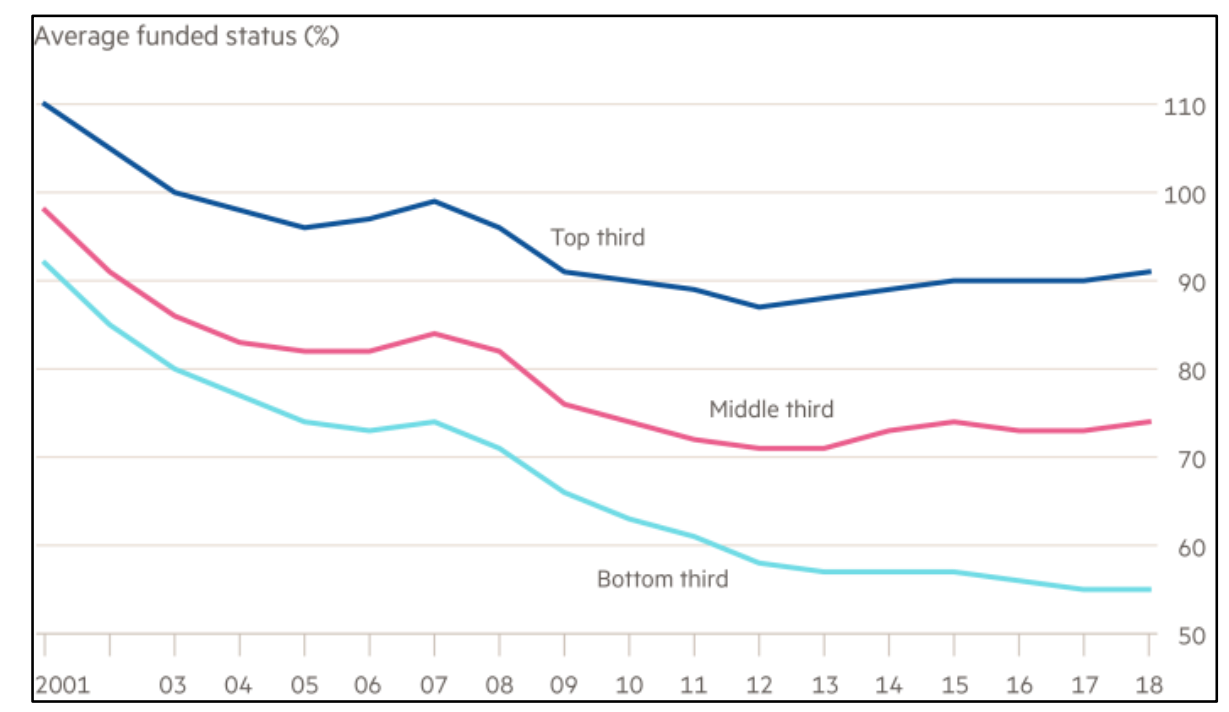

\section{Figure 2: Strains increase across weakest third of US public pension plans}

Source: Flood, 2019

Customers' perception of extremely volatile stock markets is one reason for the reluctance to invest in individual stocks and investment funds. Another reason for this is that investment advice from financial institutions, which are intended to enable consumers to choose financial instruments that are appropriate for them, are increasingly viewed critically in the public eye. This has been particularly evident since the financial crisis, in which investors only realized the dangers of many financial products and inadequate financial advice were discovered. The main point of criticism at the financial institutions is a lack of advisory quality due to product-oriented and commission-oriented sales instead of consistently aligning the advice to the actual needs of investors. A consequence of the individual lack of quality of advice and their public discussion is an increasing deterioration in trust in investment advisors and financial institutions. Many consumers are often not aware of the conflicts of interest between both parties. These arise primarily from the advisory fee through commissions of different amounts depending on the investment product. Therefore, consultants can have an incentive to sell products with high commissions that are not always beneficial to the customer. A lack of financial knowledge among many consumers leads to a great dependence on the goodwill of the financial institution and its investment advisors (Gulden, 2018, pp. 1-2). 


\section{International Journal of Business and Applied Social Science (IJBASS)}

E-ISSN: 2469-6501

VOL: 6, ISSUE: 4

April/2020

DOI: 10.33642/fjbass.v6n4p4

CPER

https://iibassnet.com/

CCenter for Promoting Education and Research (CPER) USA

WWW.cpernet.org

The growing variety of offers provides countless investment opportunities. Risks such as interest rate risks, exchange rate risks or share price risks must also be taken into account, as they can consume the already low earnings or even lead to negative results, particularly in low-interest periods such as those that have occurred since 2010 (Lindmayer \& Dietz, 2020, p. 1).

\section{Objectives}

Primarily financial knowledge in different contents areas has a significant impact on retirement planning, retirement savings activities, and retirement investment management, however, with the most marked impact on the investment management phase (including the choice of financial instruments). This is consistent with prior findings of studies separately investigating these stages and taken together, it provides the important insight that financial literacy makes a difference no matter if the current objective of the individual is to plan for the income stream after retirement, to decide whether or not to save for retirement, or to make investment decisions about which assets to hold in the retirement portfolio (Hauff et al., 2019). Financial knowledge dimensions have a significant and positive effect on the investment decisions of investors (Silvester, 2019).

A constructive and forward-looking approach to private finances and long-term investment strategies and wealth accumulation are becoming increasingly important (Müller, 2020, p. 1). The timely and long-term financial provision decreases worries and fears, about the security in old age, but also concerning the risk of losing the previous standard of living. It is important to look more closely at the own financial perspectives in the coming years and decades because shortly before retirement age, it might be too late to build up an additional pension in addition to the statutory pension or company pension (Hintze, 2019, p. VI). The first step towards a sound investment that also takes taxes into account is to start planning long-term investment decisions as soon as possible (Lindmayer \& Dietz, 2020, p. 1).

Once an investment strategy has been developed, it should be kept for a while. Concluding new contracts and interrupting old ones usually only generate costs and little added value. This does not mean that investment strategies should not be regularly checked and adapted to changing framework conditions. These primarily include changes in the personal environment (job, family), but also the financial markets and tax legislation (Hintze, 2019, p. 4).

This paper is intended to provide an up-to-date overview of current investment strategies for private individuals as small investors in times of low-interest-rates to subsequently establish and create sound and reasonable financial planning.

Research methodology
Besides a detailed current literature review and subsequent critical analysis on that topic, the qualitative approach of the problem-centered interview is chosen for the empirical part and the collection of the data for this study. Through the openness and flexibility of this method, the discovery of unknown facts is made possible, higher information content is generated and the viewpoint of the interviewees is centered. The objective of the empirical study is the identification of current and reasonable investment strategies for private individuals as small investors in times of low-interest rates.

The data collection will be conducted by guided and problem-centered interviews. The basis for the preparation of the interview guide and the related questions are the information and knowledge base from the current literature on this topic. The interview guide consists of an introduction and the main part. The introduction serves to briefly outline the meaningfulness and usefulness of the survey. In the main section, questions are asked about possible reasonable investment strategies in times of low-interest rates. When conducting the interviews, it has been tried to ask open questions where possible and appropriate to gain as much information as possible from the interviewee and not lead him/her in a specific direction (Mayring, 2016, pp. 67-68).

The problem-centered interview selects a linguistic approach to determine the respective position based on subjective meanings. It's tried to establish a situation of trust between the individual parties. Although the interview partners are directed by the guideline through certain questions, they react openly and without any specific answer possibilities. This approach has the advantage of being able to check the general understanding of the interviewees as well as the disclosure of subjective opinions and the discussion of concrete terms of the interview situation (Mayring 2016, pp. 68-69). The areas of application for the problem-centered interview are mainly within theory-based research since it integrates the aspects of the primary problem analysis into the interview. It is particularly suitable if in principle a lot is already known about the research field, which is the case regarding the main topic of this study. The standardization through the interview guide facilitates the comparability of the conducted interviews (Mayring, 2016, pp. 70-71).

The evaluation method is based on the summary approach of the qualitative content analysis according to Mayring. The entire material is screened without any specific preliminary considerations and the respective recordings of the interviews are transcribed. In a further step all utterances, which do not change the content, are removed since the main interest is aimed only at the content-based information (Mayring, 2016, pp. 115-116). Comprehensive content analysis 
is used for the data evaluation. The aim is to reduce the material to its essential contents and to create a manageable basic form. Written statements will be structured to subsequently conclude the objectives of this study. The results will be analyzed and put into context with the relevant literature (Mayring, 2016, pp. 115-116).

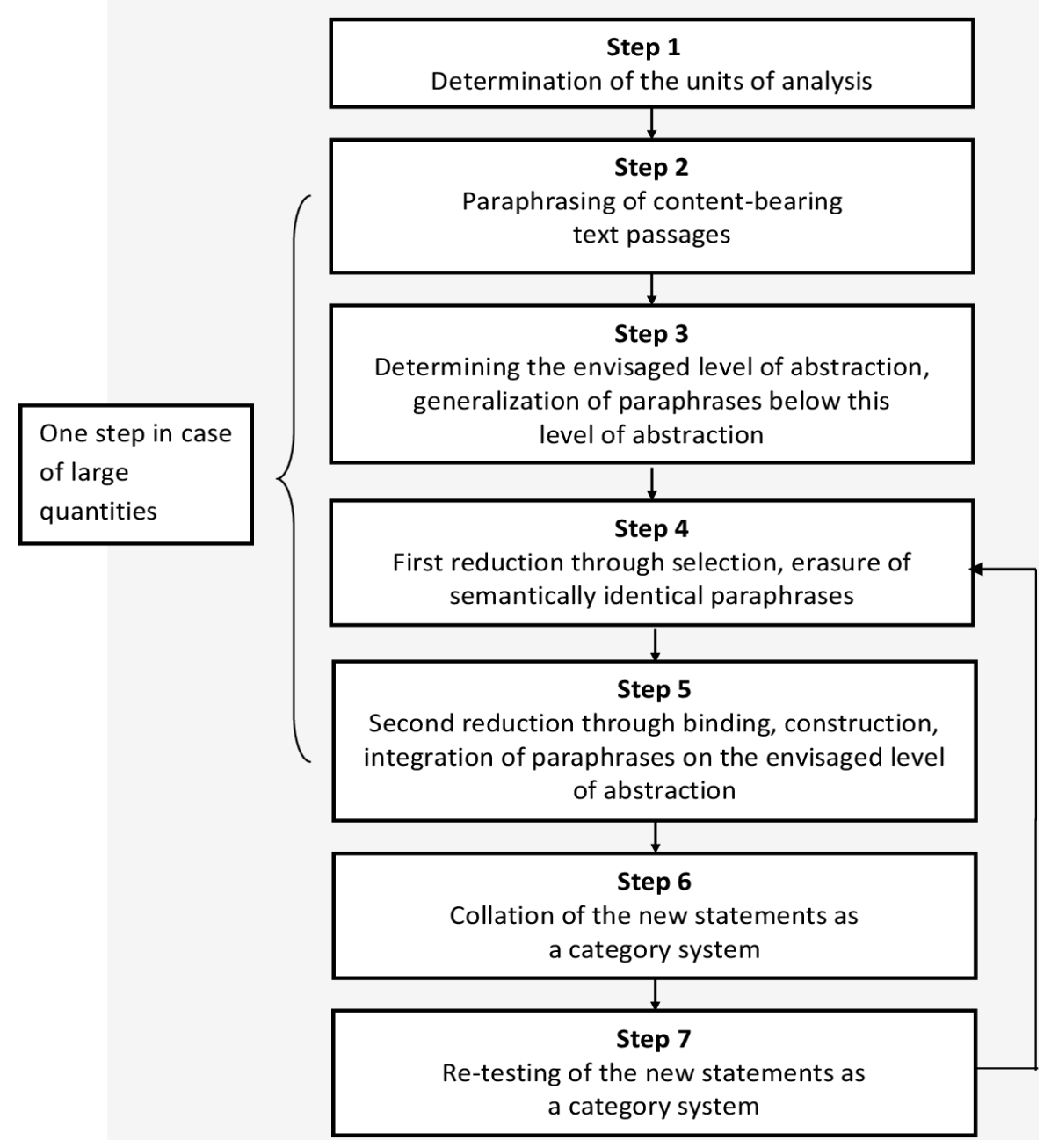

Figure 3: Step-by-step model of summarizing content analysis

Source: Mayring, 2000

Constantia Flexibles is one of the world's leading manufacturers of flexible packaging. The group supplies its products to numerous multinational corporations and local market leaders in the food, pet food, and pharmaceutical industries. In recent years the group has developed from a supplier with a strong European regional focus into a group that is active on a global basis in the world's most attractive and fastest-growing market for flexible packaging. Headquartered in Vienna, around 8,500 employees are working worldwide in 38 plants in 16 countries (http://cflex.com/de/ueber-uns/, retrieved on March 24th, 2020). In order to gain access to the field and the widest possible knowledge spectrum, finance representatives of various hierarchy levels of the Pharma Division will be asked in the empirical setting. The selection criterion of the finance representatives is a direct relation to investment strategies in their day-to-day work. For this purpose, as shown below, six employees are selected who, in order to ensure anonymity, are named in this study only with their professional job title.

1. Senior Vice President Pharma

2. Head of Finance and Reporting

3. Head of Controlling

4. Senior Controlling Pharma

5. Accounting \& Treasury Expert

6. Accounts Receivable Expert

The data collection has been carried out in a specific, pre-defined period. The general readiness for the interview and the subsequent evaluation of the obtained information was clarified via preliminary information by e-mail or telephone. Afterward, an appointment for a phone call-based interview was arranged. The readiness for the audio recording of the conversations has also been requested in advance. In the course of a test run of the interview at one selected interview partner, the general suitability of the interview guide was checked. Since no problems and 
E-ISSN: 2469-6501

VOL: 6 , ISSUE: 4

April/2020

DOI: $10.33642 / f j b a s s . v 6 n 4 p 4$

CPER

https://iibassnet.com/

\section{CCenter for Promoting Education and Research (CPER) USA}

WwW.cpernet.org

difficulties could have been observed, the prepared guide has not been further modified and the result of the interview of the preliminary study was directly incorporated into the main study.

\section{Investment Strategies for private individuals}

A responsible investment strategy is ideally based on the criteria of security, profitability, liquidity, tax optimization and sustainability (Lindmayer \& Dietz, 2020, p. VI). In general, a distinction can be made between forms of monetary investments and asset investments. Monetary investments generally serve to maintain liquidity. They give the investor the right to payment of a certain amount on a date that is usually set in advance. Monetary investments offer fixed, even if in the current low-interest phase, mostly calculable income and are usually more liquid than asset investments (Lindmayer \& Dietz, 2020, p. 2). Significant predictors of investment decision intention through financial attitude are risk tolerance, financial interest, financial awareness, and knowledge, perceived behavioral control and subjective norms (Kumari \& Pandey, 2020).

The most important monetary investments are then listed, described and a critical assessment based on the current literature and the results of the qualitative research of this study are done.

\section{Savings book}

Definition: A savings book is a document that certifies a claim by the holder against a bank. Savings certificates may only be issued by credit institutions authorized to make savings deposits. The income that savings deposited with a bank generate is largely dependent on the amount of the interest rate and the term (due daily, fixed for a certain period) of the savings book. However, the income is reduced by the capital gains tax (on the interest income). A distinction is made between variable and fixed interest savings books. Another form is the capital savings book, which is usually characterized by higher fixed interest rates and longer agreed terms. In the event of bankruptcy of the financial institution, the deposit guarantee comes into effect. Insolvency affects all amounts that exceed the deposit guarantee (Fischer \& Wagner, 2017, p. 14).

Critical assessment: A savings book is among the most conservative investment products and is, in general, a safe form of investment (Rieksmeier, 2010, p. 60). Savings books with fixed interest rates are subject to the risk of changes in interest rates. If a savings book is closed with fixed interest rates for a certain term, the benefit from an increase in the interest rate level doesn't take place. A savings book is generally recommended for an investment period of 1 to 3 years. If the money is not needed for a longer period, an alternative form of investment is recommended due to inflation (Lindmayer \& Dietz, 2020, p. 552). In Austria, the average inflation rate from 2010 to 2019 was around $1.9 \%$. There were years with $0.9 \%$ (2015 and 2016) and years with $3.3 \%$ (2011). An average inflation rate of $2.1 \%$ is forecast for 2020 (https://de.inflation.eu/inflationsaten/, retrieved on March 25th, 2020). Historically, the average inflation rate in Austria since the introduction of the currency Euro [€] as a means of payment has been around $2 \%$ per year. Accordingly, prices rise by an average of $2 \%$. In other words, in real terms, money is reduced by $2 \%$ each year (without interest). The current interest rates for savings books can be retrieved very quickly and easily on the Internet. If the money is tied up in a savings book for three years, the best case is $0.35 \%$ interest (https://www.bankenrechner.at/, retrieved on March 25th, 2020). This interest rate is nowhere near sufficient to maintain purchasing power at the inflation rate explained before (Edling, 2019, p. 122). For these reasons, a savings book is only recommended for brief interim storage of the money (Müller, 2020, p. 160). The reason why the savings book is still used for medium and long-term savings is the fear of investing in other types of investment. A savings book is the safest investment in the short term, but in the long term, after deducting taxes on interest and after deducting inflation, it may only be lossy, whereas it's the worst form of investment (Gerner, 2010, p. 69). 
Table 1: Inflation rate forecasts in Austria from 2020 to 2024

\begin{tabular}{|c|c|c|c|c|c|}
\hline & 2020 & 2021 & 2022 & 2023 & 2024 \\
\hline $\begin{array}{r}\text { WIFO: Austrian Institute for Economic Research } \\
\text { (Status: March, 2020) }\end{array}$ & $1.3 \%$ & - & - & - & - \\
\hline $\begin{array}{r}\text { HIS: Institute for Advanced Studies } \\
\text { (Status: March, 2020) }\end{array}$ & $1.3 \%$ & - & - & - & - \\
\hline $\begin{array}{r}\text { BMF: Federal Ministry of Finance } \\
\text { (Status: March, 2020) }\end{array}$ & $1.5 \%$ & $1.6 \%$ & $1.6 \%$ & $1.6 \%$ & - \\
\hline $\begin{array}{r}\text { Bank of Austria } \\
\text { (Status: March, 2020) }\end{array}$ & $1.2 \%$ & $2.0 \%$ & - & - & - \\
\hline $\begin{array}{r}\text { EU commission } \\
\text { (Status: February, 2020) }\end{array}$ & $1.6 \%$ & $1.5 \%$ & - & - & - \\
\hline $\begin{array}{l}\text { UN: United Nations } \\
\text { (Status: January, 2020) }\end{array}$ & $2.1 \%$ & $2.0 \%$ & - & - & - \\
\hline $\begin{array}{l}\text { OeNB: National Bank of Austria } \\
\text { (Status: December, 2019) }\end{array}$ & $1.4 \%$ & $1.5 \%$ & $1.6 \%$ & - & - \\
\hline $\begin{array}{r}\text { OECD: Organization for Economic Cooperation and } \\
\text { Development (Status: November, 2019) }\end{array}$ & $1.6 \%$ & $1.7 \%$ & - & - & - \\
\hline $\begin{array}{r}\text { IWF: International Monetary Fund } \\
\text { (Status: October, 2019) }\end{array}$ & $1.9 \%$ & $1.9 \%$ & $2.0 \%$ & $2.0 \%$ & $2.0 \%$ \\
\hline
\end{tabular}

Source: "Inflation rate forecasts in Austria from 2020 to 2024", 2020

It is still unclear how the events currently taking place worldwide due to the Coronavirus (Sars-CoV-2) and the disease COVID-19 caused by it, will affect the development of the inflation rate.

\section{Building loan contract}

Definition: Building societies are among the special banks. In addition to a few independent building societies, each major bank and the public law and cooperative institutes have their building society (Gulden, 2018, p. 22). Building loan contracts are often seen as a popular alternative to savings books (Raab, 2019, p. 221). When it comes to building loan contracts, it can be chosen between fixed and variable interest rates. The conditions can vary between individual building societies. There is usually an upper and lower interest rate limit. The state often pays a premium in a single-digit percentage of the savings made (Prack \& Czerwionka, 2015, p. 106). The amount of the bonus is set annually. Each person can conclude a maximum of one building loan contract and can therefore only claim a government premium once (Reifner, 2017, p. 300). The statutory minimum term for building loan contracts must be taken into account. If the building loan contract is terminated prematurely (exception: the creation of new living space), the state premium is retained (Lindmayer \& Dietz, 2020, p. 125). Also, there is a reduction in the interest rate or termination fees. Deposit insurance also applies to build loan contracts (Rieksmeier, 2010, pp. 90-91). Most EU building societies and credit institutions that provide building loan contracts have signed the European Code of Conduct. Accordingly, every prospective customer has to be given a consulting brochure, which was drawn up uniformly by all building societies that have signed the code (Lindmayer \& Dietz, 2020, p. 127).

Critical assessment: Building loan contracts are very often advertised by financial institutions (Müller, 2020, p. 86). In Austria, for example, around $70 \%$ of the population have a building loan contract. At the current interest rate level (as of 2020), a building loan contract in Austria yields an average of $0.4 \%$ to $0.9 \%$ in interest per year. That means, for example, if the building loan contract is saved up with $€$ 100.00 per month, a profit of around $€ 200.00$ can be achieved after 6 years (including a state premium). After the deduction of the capital gains tax, around $€ 150.00$ remain. If an inflation rate of around $2 \%$ is assumed, the purchasing power will be reduced by around $€ 275.00$ in real terms. The interest income on home savings contracts is currently very low and the money invested is worthless in real terms each year. The money is also committed for 6 years (or longer). If the money is accessed before the agreed term has expired, further losses can be expected. Banks often try to hide the bad interest rate with lure offers (e.g. 1.5\% interest in the first year). The offer does not change because the money invested 


\section{International Journal of Business and Applied Social Science (IJBASS)}

E-ISSN: 2469-6501

VOL: 6, ISSUE: 4

April/2020

DOI: 10.33642/fjbass.v6n4p4

is not increased (Horn \& von Schrottenberg, 2011, p. 123). In the current interest rate environment (as of 2020), a building loan contract is therefore not recommended.

\section{Daily allowance}

Definition: A daily allowance account is an interestbearing account. Interest rates are variable and are usually above the savings book (Horn \& von Schrottenberg, 2011, p. 163). The funds deposited into a daily allowance account are available daily (Müller, 2020, p. 90). There are no notice periods like with the time deposit. Deposits can be made from any account using normal bank transfers. General payments cannot be made from a daily allowance account. The funds in the daily allowance account can only be transferred to a so-called reference account (i.e. checking account). This provides additional security (Fischer \& Wagner, 2017, p. 12). The funds in a daily allowance account are subject to deposit insurance (Edling, 2019, p. 85).

Critical assessment: The main advantages of investments in the form of daily allowance result from the relatively high-interest rates, which are typically higher than the usual interest rates for savings books (Lindmayer \& Dietz, 2020, p. 74). Further advantages consist of the daily availability of the entire credit balance and the high level of security of the investment, which is guaranteed by the legislator and also increased by most credit institutions. Also, daily allowance investors are not charged any fees for opening a daily allowance account or for maintaining it. Compared to a current account, however, a daily allowance account has only limited payment functions and is not suitable for handling everyday banking transactions. For example, the usual direct debit procedure for daily allowance accounts is not accepted (Müller, 2020, p. 100). It is essential to ensure sufficient liquidity at all times. A reserve of a few thousand euros, for example on a daily allowance account, should be kept available for unforeseen larger repairs, regular larger purchases and the other unexpected cases of life (Lindmayer \& Dietz, 2020, p. 32). The success of daily allowance accounts also led to less use of the savings book (Fischer \& Wagner, 2017, p. 16).

\section{Time deposit}

Definition: Time deposits are short to medium-term investments in which an agreed amount of money is invested with a bank over a fixed term (investment period) and at a fixed interest rate. Time deposits usually run between six months and ten years. An investment is liquid if the money is available at all times. The money in the current account or daily allowance account can be used at any time. Shares, bonds, and fund units can usually also be sold daily (at the current stock price). A time deposit account cannot usually be closed quickly, so it is not liquid (Müller, 2020, pp. 9091).
Critical assessment: Compared to other savings models, such as daily allowance, the interest for time deposits is generally higher, since the bank can dispose of customers' money for fixed deposits for several months or even years. Also, the interest rate for the time deposit is guaranteed by the bank over the entire previously agreed term or investment period. This is a further difference from daily allowance, which bears interest at variable interest rates, i.e. can even be influenced by short-term events on the financial markets. The interest for time deposits will be credited at the end of the term. In the case of time deposits over several years, investors usually also benefit from reinvestment. This means that the interest income is not paid out immediately, but is automatically reinvested in the same account, i.e. is added to the deposit amount, which means that investors benefit from the compound interest. Since the liquidity of time deposits is lower compared to the current account, the interest is a bit higher. However, you rarely get more than $0.5 \%$ interest at the moment. The time deposit account is therefore not a real investment, but useful for bridging (Müller, 2020, p. 101).

\section{Money market funds}

Definition: Money market funds are special funds that are allowed to invest up to $100 \%$ of their capital in bank deposits, daily allowance and short-term time deposits, as well as other securities with a short remaining term or regular interest rate adjustments. Money market funds are particularly suitable for the investment of funds that should be available at any time at short notice for any expenses that may arise shortly (Raab, 2019, p. 72). Unlike bank deposits, money market funds are not subject to deposit insurance. Because of the low risks of separating the fund from the company's assets, this is not a decisive disadvantage (Lindmayer \& Dietz, 2020, p. 250).

Critical assessment: Due to the short remaining term of the debt instruments contained in the fund assets, money market funds have practically no price risks. Their return is influenced almost exclusively by the level of the short-term interest rate. If this remains constant, its value increases practically continuously, but with a very low rate of increase. If such funds were previously parked on the savings book, money market funds have now largely assumed the function of liquidity storage. Some of the money market funds are offered without a front-end load and are therefore suitable for investments of just a few months. However, it also makes sense to use money market funds in the longer term to invest liquidity (Raab, 2019, p. 72). Due to the high investment amounts, the managers of money market funds can agree relatively good conditions with the banks with which they invest the fund assets. Even after deducting the fees withheld from management, the returns 


\section{International Journal of Business and Applied Social Science (IJBASS)}

E-ISSN: 2469-6501

VOL: 6, ISSUE: 4

April/2020

DOI: 10.33642/fjbass.v6n4p4

from money market funds are usually still above what private investors can achieve with individually negotiated fixedterm deposits or savings book investments. In contrast to many other fund types, there is usually no front-end load for money market funds. Money market funds represent a liquid alternative to time deposits or savings books with financial institutions and are also a profitable interim solution for equity investors who are looking for a "parking position" or who later anticipate a new upswing on the stock exchange. The return on a fund is usually higher than the interest achievable for short-term deposits. In addition to the high level of liquidity, an advantage of money market funds is that there are usually no front-end loads to pay and the internal (fund) costs are low (Lindmayer \& Dietz, 2020, p. 250).

\section{Bonds}

Definition: Bonds are so-called interest-bearing securities. They are also called fixed-income securities and are an important means of external financing. The holder of the bond has the right to receive the leased capital and the agreed interest. Bonds are debt capital that is made available to companies by external investors (Fischer \& Wagner, 2017 , p. 28). The similarities with a bank loan are initially quite large. Lenders (creditors) provide the borrower (the debtor) with a certain amount of money for a specified period. For this, the creditor receives the right to full repayment of the capital including interest. However, in the case of a bond, the repayment is usually due and not as in the case of a loan as part of repayment installments. Also, bonds are not only bought or issued by a particular investor. Instead, there is usually a public issue so that a large number of investors can buy corporate bonds. As a result, the potential financing volume increases significantly. Investors can earn returns by buying bonds in two different ways. Ordinary income is defined as the fixed interest payments that the borrower usually pays annually. It is a fixed value that is determined in advance and the amount of which depends on the creditworthiness of the issuer. The more negative the credit check of an (external) rating agency is, the higher the interest rate to be paid. The second type of income is price increases because bonds can be traded on the stock exchange (Lindmayer \& Dietz, 2020, pp. 169-170).

Critical assessment: Bonds can be traded on the stock exchange and are often already tradable in small denominations. This can also make them attractive to small investors. The interest is usually higher than the savings interest and the investor can choose between different forms according to the investment strategy. The main types of bonds are corporate and government bonds. Investors are exposed to the risk of bankruptcy or insolvency of the issuer. This can lead to a partial loss of the capital invested up to a total loss. This risk is only mitigated for the covered bonds (mortgage bonds), as they are the only secured, not subordinated form of bonds. The rate of the bonds can fluctuate. It can be influenced by general interest rate developments, general economic developments, creditworthiness and other factors influencing the exchange rate. The issuer is not obliged to regularly offer to buy and to sell prices. The liquidity risk consists in the fact that the securities cannot be sold temporarily or over the long term or at prices that are not in line with the market. With fixed-income securities, there is a risk that the current interest rate level on the bond market may rise above the nominal interest rate during the term of the bond. For bonds that are traded in a foreign currency, an unfavorable price development can lead to price losses. For non-inflation-linked bonds, which represent the majority of all bonds, there is a risk of a real loss about the number of future payments. European government bonds lend themselves to the security-conscious portion of an investment portfolio. Since this is about minimizing risk, the return should be largely ignored. Accordingly, short-term bonds from countries with a high credit rating, i.e. high credit and credibility, are recommended (Müller, 2020, p. 150).

In the case of asset investments, the focus is on longer to long-term investments, in which the tangible asset and thus the maintenance of the intrinsic value is of central importance. The return is usually not fixed in advance. For example, providers' earnings prospects are often continued from past data for the future. However, past developments alone do not provide a sufficient indicator of future developments, especially for real estate or investment funds. On the other hand, tangible assets offer growth opportunities or an increase in value, such as shares. But greater opportunities also harbor greater risks. Economic, political and other uncertainties can also cause price losses or impairment (Lindmayer \& Dietz, 2020, pp. 2-3). The most important asset investments are then listed, described and a critical assessment based on the current literature and the results of the qualitative research of this study are done.

\section{Shares and equity funds}

Definition: Shares are generally property stakes in a company. Shares can be held by just one person or by several. These companies or the respective owners often decide to trade their shares on the stock exchange to attract investors. The motivation for listing the shares on the stock exchange is always the goal of getting new money for the company by selling the shares, i.e. strengthening equity. In this respect, each share represents a small part of the total share capital of a company. A share is also security that certifies the share of a shareholder in a company. This share also means voting rights at the company's general meetings, where important decisions for the company are generally made once a year. Furthermore, the share symbolizes the 
rights and obligations that the holder of the security acquires from the company through the purchase (Lindmayer \& Dietz, 2020 , pp. 152-153). An equity fund, on the other hand, is a bundle of shares from several companies that are put together, for example, by investment companies. An equity fund usually has to include a large number of different stocks. This diversification is intended to reduce the risk for investors (Raab, 2019, pp. 63-64). Funds can be divided into different categories, depending on which shares are bundled in it. There are, for example, index funds that exactly replicate a certain stock index. There are also country funds in which investments are only made in the shares of one country, as well as a large number of other funds with special investment strategies (Lindmayer \& Dietz, 2020, pp. 209-210). Common to all funds is that there is a predetermined investment strategy that is implemented by the fund management. Investing as a private investor in equity funds means less effort. The fund manager selects his buying and selling decisions based on specific guidelines. The respective fund value is determined and published every trading day. A certain fund and the desired investment amount are selected based on the information you have acquired yourself or with the help of a consultant (Müller, 2020, p. 123). Fund shares can generally be bought and sold daily at their respective market values. A one-off sales charge $(2-5 \%)$ is often required when purchasing. These costs have to be recouped through course gains. Some banks and fund companies offer special promotions, where a reduced or even no offering premium is payable. Fund management regularly incurs additional costs. Depending on the complexity of the administration, this is approximately $0.5-2 \%$ per year, depending on the fund company. These costs are deducted directly from the fund value. The positive and profitable development of the respective fund depends heavily on the quality of the respective fund management.

Critical assessment: The direct purchase of shares has the advantage that the shares can be freely selected and combined. The proportion of a share in the total portfolio can also be determined. Shares make it possible to react specifically and independently to movements in the market and other events. Shareholders receive dividend payments.
Shareholders have a direct stake in the company, which gives them rights and obligations. Voting rights can directly influence processes and decisions in the company. Shares can generally generate higher profits than equity funds. In extreme cases, however, a total loss of shares is possible and all the money invested can be lost. This can practically not happen due to the risk diversification in an equity fund. The time factor plays an important role. With a promotional fund, the daily research work is left to the fund management. When investing in stocks, the market, the news, and all possible price-influencing factors must be observed and reacted to (buy or sell) accordingly daily. The willingness to take risks is also crucial. Riskier variants may be more profitable. Less profitable strategies are also less risky (Müller, 2020, p. 122).

\section{Special form: ETF (Exchange Traded Funds)}

Definition: An ETF is an exchange-traded index fund that tracks the performance of an equity index. Essentially, ETFs combine the advantages of stocks and funds in one product. ETFs, enable cost-effective investments with one bond in entire markets. In addition to stocks, ETFs can also be used to invest in many other asset classes. Because of this diversity, ETFs are ideal building blocks for private investment strategies. ETFs can be traded on the stock exchange at any time. The range of ETFs is constantly growing and there are many combinations of different asset classes. An investment via ETFs in stocks, bonds, currencies, and commodities is possible. In practice and current theory, many market participants in the financial markets agree that it is very difficult to "beat the market in the long run". It can, therefore, make sense for a private investor not to rely on active management of stocks, but rather to keep the so-called market portfolio. In practice, the broadest possible index is used as the market portfolio. This shows the companies it contains in proportion to their market capitalization. Index funds replicate an index by the fund replicating the values contained in an index in equal proportions. This is also referred to as passive management since no fund managers actively manage the portfolio and invest in individual stocks and overweight or underweight them compared to an index (Lindmayer \& Dietz, 2020, p. 262).

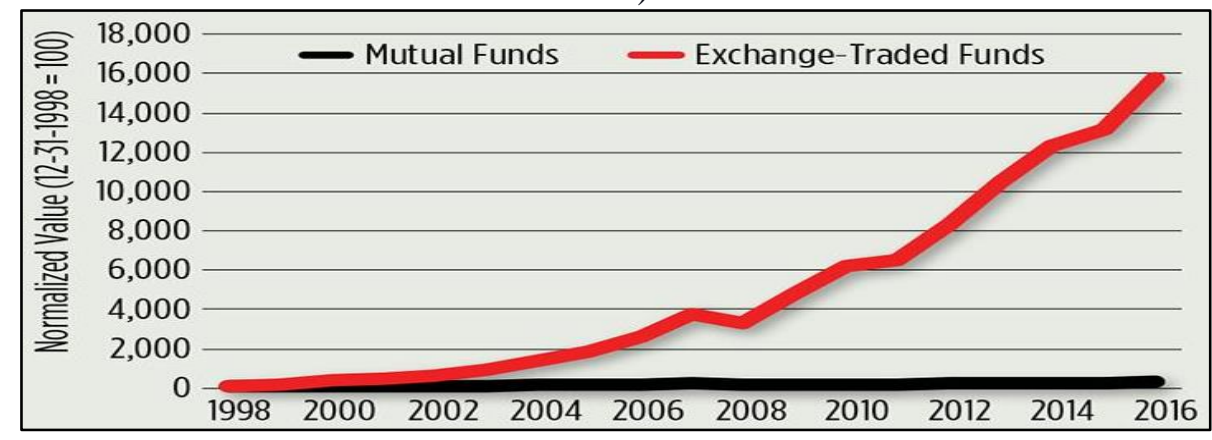




\section{International Journal of Business and Applied Social Science (IJBASS)}

E-ISSN: 2469-6501

VOL: 6, ISSUE: 4

April/2020

DOI: 10.33642/fjbass.v6n4p4

CPER

https://iibassnet.com/

CCenter for Promoting Education and Research (CPER) USA

WwW.cpernet.org

Critical assessment: Hardly any other asset class has seen such growth over the past few years as ETFs. The ability to replicate the performance of a large number of indices and markets not only transparently but also with low costs is convincing. Especially in times of crisis, when many actively managed funds were wrecked (Gerner, 2010, p. 54). There are now countless books, booklets, YouTube videos and blogs about the topic ETF. Interest in ETFs has increased significantly in recent years, with the first index fund launched in 1976 in the United States. Especially since the 2007/2008 financial crisis, ETFs have become increasingly popular. The financial crisis made it clear that hardly any fund manager had been able to correctly forecast the crisis or the subsequent upswing during this time. That shook confidence in the financial industry. Combined with the low-interest rates of recent years, this loss of confidence has prompted many private investors to look around for alternatives and take the finances into their own hands (Müller, 2020, p. 128). ETFs traded on the stock exchange have the advantage for private investors that lower front-end loads and management fees are payable. Because active asset management is not required, investing in a fund that replicates an index can pass on lower costs to clients. A major advantage of index funds is, therefore, the cost advantage. Another advantage is liquidity through tradability on a public stock exchange (Lindmayer \& Dietz, 2020, p. 262). Various studies conclude that active investment funds underperform their benchmark and that in many cases the costs for active management are not justified (Gulden, 2018, pp. 59-60). Some ETFs invest in the global stock market and hold stocks of several thousand companies. Such an ETF is diversified, meaning that it is broad and thus spreads the risk. If one, two or more of these companies file for bankruptcy out of the large number of companies included in the ETF, this is completely irrelevant from a private investor perspective. The likelihood that all of these companies will go bankrupt at the same time is extremely low and close to zero. Only ETFs offer the opportunity to invest in this large number of companies with small amounts of money. The definition of an ETF can be viewed at any time, as can its composition. This means that ETFs are significantly more transparent than actively managed funds, which in most cases only reveal the composition of the last quarter in retrospect. The value of the respective ETF shares can also be called up in the custody account at any time (Müller, 2020, pp. 129-131). However, the use of ETFs requires that the market efficiency hypothesis holds true and that all information is priced in an efficient capital market. In this case, it is not possible to generate excess returns through analyzes or evaluations, and active management of investments is not justified. ETFs will therefore only be used if investors believe in the market efficiency hypothesis. Since the majority of consumers are not aware of this due to a lack of financial knowledge, this fact usually does not play a role in the consumer decision of private customers, especially in the mass customer business (Gulden, 2018, p. 60).

Real estate funds

Definition: Real estate funds are investment funds that invest in real estate. The investment fund collects funds from investors and invests them directly or indirectly in apartment buildings, commercial buildings, and commercial properties. A real estate fund usually focuses on real estate from a specific region. As is usual for investment funds, fund managers manage the fund's assets. They divide the total capital of the investors into different investments. This diversifies the portfolio to reduce investment risk. Each investor receives securities for the assets invested (Gerner, 2010, p. 210). These real estate certificates represent the respective share of total capital and the fund income generated with it. Commercial real estate is the focus of many real estate funds. The return on a real estate fund comes from regular rental income and possible increases in property value. There are open and closed real estate funds (Raab, 2019, p. 73). Open-ended funds are the normal investment funds of the fund companies. These open-ended funds can be entered and exited at any time and there is practically an unlimited number of fund units (Lindmayer \& Dietz, 2020, p. 252). The opposite is the case with closed-end funds. The number of fund units is limited. The fund is closed when a specified total investment amount is reached. In contrast to open-ended real estate funds, capital is usually only invested in one or two properties in closed-end real estate funds (Rieksmeier, 2010, p. 25). This increases the fund risk. Closed-end funds are therefore more speculative and therefore more suitable for more experienced fund investors (Lindmayer \& Dietz, 2020, p. 42).

Critical assessment: Significantly less capital is needed for an investment in a real estate fund than if you buy property directly for investment. Real estate fund shares can already be bought with little money. The money invested is spread over several real estate investments, which is not possible for most private investors with a direct investment. However, this advantage does not apply to many closed real estate funds. The fund units are relatively easy to sell. In comparison, it takes longer to sell a property that has been bought at a reasonable price (and it also typically incurs high fees). Real estate fund investors do not incur any administrative expenses in comparison to a property they have purchased themselves. Real estate funds are also subject to a manageable risk and are therefore an interesting investment for conservative investors. However, the return prospects for real estate funds are not too high. With equity funds, better returns can be achieved depending on the risk tolerance (Horn \& von Schrottenberg, 2011, pp. 125-126). 


\section{Raw materials and precious metals}

Definition: The increase in the world's population and global industrialization are also leading to increasing demand for raw materials and precious metals. Global prosperity and population growth inevitably make raw materials a scarce commodity. The unstoppable urge for higher living standards, technological progress, increasing automation, as well as the construction and expansion of infrastructure lead to excessive use and consumption of raw materials. The increasing general scarcity of resources and the interaction with other asset classes such as stocks and bonds make investment attractive. Precious metals, base metals, energy commodities as well as agricultural commodities offer various possibilities to invest in this asset class. Investing money in precious metals (e.g. gold, silver, platinum, palladium, etc.) is one of the oldest forms of investment by mankind (Lindmayer \& Dietz, 2020, p. 3). Precious metals are seen as crisis investments and value preservation instruments because they cannot be multiplied at will. The uncertainty on the financial markets, the enormous increase in money, rising public debt, burgeoning fears of inflation and the negative real interest rate are causing an increasing demand for real assets to protect one's assets (Horn \& von Schrottenberg, 2011, p. 54).

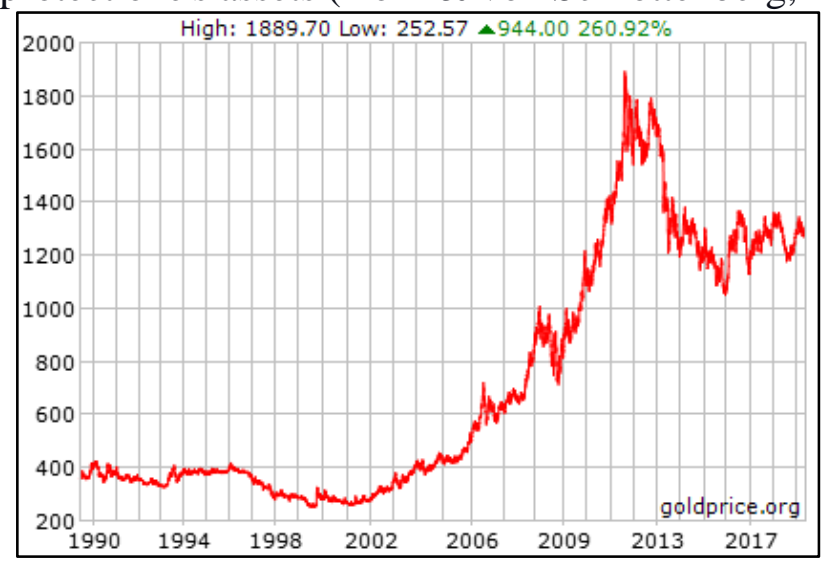

\section{Figure 5: 30 Year Gold Price History in US Dollars per Ounce}

Source: "30 Year Gold Price History in US Dollars per Ounce", 2019

Critical assessment: Investing in raw materials and precious metals is particularly popular in times of high uncertainty about the stability of the financial systems. Since the bankruptcy of the US investment bank Lehman Brothers, the focus of investors has shifted to raw materials and precious metals. The gold price, for example, has almost doubled within a few years. Gold is one of the few precious metals that are in massive demand. It has been a constant investment for centuries (Reifner, 2017, p. 55). Gold is inflation-proof and therefore value-preserving (Horn \& von Schrottenberg, 2011, p. 105). However, direct investment in precious metals also has disadvantages. The main disadvantage of a direct investment in raw materials or precious metals is the lack of income in the form of a secure annual return. The private investor can only benefit from price increases. It can take years for the desired return to be achieved. The annual assessment of success does not look particularly good for investments in raw materials or precious metals. On the other hand, the return in the total period can be positive. The volatility (price fluctuation) of precious metals is significantly lower than i.e. stocks. This means that if the investment needs to be liquidated, the investor is very likely to get the capital back because the selling price is relatively stable. However, the lack of volatility limits the short-term success of the investment. Thus, gold or other precious metals are hardly suitable for short-term speculation under normal market conditions. Commodities and precious metals are suitable for diversifying the portfolio, as these often have a negative correlation to the asset classes stocks, bonds, and real estate. To obtain a corresponding diversification, a share of approx. $10 \%$ of the portfolio should be aimed for. The problem with this type of investment is that although it participates in the performance, there is usually no right to physical delivery, but the actual possession of precious metal is valuable in times of great uncertainty (Lindmayer \& Dietz, 2020, pp. 228-230).

\section{Discussion \& Conclusions}

Personal advice is not necessary for many aspects of private investment strategies. There are many sources of information in books, on the Internet or in public places. Financial advice from a bank has a fundamental problem. The consultant earns especially when the customer completes a product. The advice itself is free. There is, therefore, an incentive for the advisor to sell the customer a product of the financial institution, regardless of whether the customer needs this product or not. Financial institutions and insurance companies make money from customers buying products. The supposedly free advice is in no way free of charge. For example, there are front-end loads on funds and annual management fees that are payable for each contract. 


\section{International Journal of Business and Applied Social Science (IJBASS)}

E-ISSN: 2469-6501

VOL: 6, ISSUE: 4

April/2020

DOI: 10.33642/fjbass.v6n4p4

CPER

https://iibassnet.com/

(C) Center for Promoting Education and Research (CPER) USA

wwW.cpernet.org

In addition to the statutory pension, there are many options for making provisions for later with various pension products and insurance. Pension or insurance products are not an alternative to investing in the capital market, they are just a suitable addition. In the long term, significant growth in wealth can only be achieved by participating in the capital market. So, it makes sense to combine security through pension products with return through stock investments.

An investment strategy that is currently very widespread and becoming increasingly popular is an ETF savings plan. Overall, global diversification across various asset classes (stocks and bonds), regions, industries, and companies are achieved. Passive income is built up by investing in bond ETFs and dividend ETFs. At the same time, you participate in the performance of the global stock markets and, last but not least, potentially high price gains can be achieved.

In the short and medium-term, gold and many other raw materials and precious metals are subject to strong fluctuations. Nevertheless, due to geopolitical uncertainties and other factors, the gold price should develop positively in the longer term. However, as always in the past, the development of the gold price is difficult to predict, since psychological motives such as uncertainty and fears about the future also influence investors' decisions. If a private investor decides to invest in gold regardless of the price development of the gold price, this can be a sensible rounding off of the investment strategy, taking into account taxes and other issues. Commodities and precious metals are suitable for diversifying the investment portfolio, as these often have a negative correlation to the asset classes stocks, bonds, and real estate. A share of approx. $10 \%$ of the portfolio is recommended by the current literature and interview partners.

An essential prerequisite for building a reasonable investment strategy and being able to survive on the financial markets in the long term is to form an own opinion. It is the basis for initiating a learning process that can ultimately develop the own investment style. Also, it protects at least to some extent from errors in mass psychology, which is a key success factor.

\section{References}

30 Year Gold Price History in US Dollars per Ounce. (2019, May 31st). Retrieved on March 30th 2020, from https://goldprice.org/30-year-gold-price-history.html.

Chen, J. (2020, Mar. 26th). Low Interest Rate Environment Definition. Retrieved on March 30th 2020, from https://www.investopedia.com/terms///low-interest-rate-environment.asp.

Edling, N. (2019). Finanzielle Selbstbestimmung: Wie Sie sich absichern und Vermögen aufbauen. Wiesbaden: Springer Verlag. DOI: 10.1007/978-3-658-23837-7.

Fischer, M. \& Wagner, D. (2017). Die Wissenslücken der Deutschen bei der Geldanlage: Eine empirische Untersuchung. Wiesbaden: Springer Gabler Verlag. DOI: 10.1007/978-3-658-16458-4.

Flood, C. (2019, Nov. 3rd). Falling interest rates wreak havoc in US pension system. Retrieved on March 30th 2020, from https://www.ft.com/content/60c5b80b-b227-405a-9290-0d5f78efa0f7.

Gerner, T. (2010). Denken und Handeln an Finanzmärkten: Zwischen Angst und Gier - Experten beziehen Position. Wiesbaden: Gabler Verlag. DOI: 10.1007/978-3-8349-8741-9.

Gulden, J. (2018). Automatisierte Geldanlage: Determinanten und Einflussbedingungen der Akzeptanz von Investment Management FinTechs. Wiesbaden: Springer Gabler Verlag. DOI: 10.1007/978-3-658-24054-7.

Hauff, J.C., Carlander, A., Gärling, T., \& Nicolini, G. (2019). Retirement Financial Behavior: How Important Is Being Financially Literate?. Journal of Consumer Policy, Original Paper. DOI: https://doi.org/10.1007/s10603-019-09444$\mathrm{x}$.

Hintze, C. (2019). Finanz-Petits-Fours: So erreichen (nicht nur) Frauen Wohlstand und finanzielle Freiheit. Wiesbaden: Springer Verlag. DOI: 10.1007/978-3-658-26407-9.

Horn, G. \& von Schrottenberg, H. (2011). Ganzheitliche Finanzplanung: Das neue Wertebewusstsein von Kunden und Beratern. Wiesbaden: Gabler Verlag. DOI: 10.1007/978-3-8349-6584-4.

Inflation rate forecasts in Austria from 2020 to 2024. (2020, March). Retrieved on March 31st 2020, from https://de.statista.com/statistik/daten/studie/290144/umfrage/prognosen-zur-entwicklung-der-inflationsrate-in-oesterreich/.

Kumari, M. \& Pandey, K. N. (2020). Psychological Determinants Affecting Investment Decision Behavior of Millennial Investors. Our Heritage, Volume 68 (Issue 30), 720-737. ISSN: 0474-90.

Lindmayer P. K. M. \& Dietz H.-U. (2020). Geldanlage und Steuer 2020: bewährte und innovative Konzepte. Tools für Anleger und Berater. Wiesbaden: Springer Gabler Verlag. DOI: 10.1007/978-3-658-27912-7. 
Mayring, P. (2000). Qualitative Content Analysis. Retrieved on March 30th 2020, from https://www.semanticscholar.org/paper/Qualitative-Content-AnalysisMayring/79363908e7e389f3f58fba6f971d7ec8043517be.

Mayring, P. (2016). Einführung in die qualitative Sozialforschung: Eine Anleitung zu qualitativem Denken. Weinheim: Beltz.

Müller, C. (2020). Finanzen - Freiheit - Vorsorge: Der Weg zur finanziellen Unabhängigkeit - nicht nur für Frauen. Wiesbaden: Springer Fachmedien Verlag. DOI: 10.1007/978-3-658-28339-1.

Prack, R.-P. \& Czerwionka A. (2015). Verkauf von Versicherungen und Finanzdienstleistungen ist (k)eine Magie: Wie Sie mit zielführenden Zaubersprüchen beim Kunden Verträge abschließen. Wiesbaden: Springer Gabler Verlag. DOI: 10.1007/978-3-658-06210-1.

Raab, W. (2019). Grundlagen des Investmentfondsgeschäftes (7. Auflage). Wiesbaden: Springer Gabler Verlag. DOI: $10.1007 / 978-3-658-24155-1$.

Reifner, U. (2017). Das Geld - Band 1: Ökonomie des Geldes - Kooperation und Akkumulation. Wiesbaden: Springer Verlag. DOI: 10.1007/978-3-658-14102-8.

Rieksmeier, M. (2010). Erklärungsnotstand Altersvorsorge: Warum selbst Experten versagen - eine Diagnose mit Therapievorschlägen. Wiesbaden: Gabler Verlag. DOI: 10.1007/978-3-8349-8558-3.

Silvester, M., Kumar, V., \& Nawaz, N. (2019). A Kaleidoscopic View on the Impact of Financial Knowledge on Investment Decision of Individual Investors. International Journal on Emerging Technologies, Volume 11 (Issue 1), 130135. ISSN: 0975-8364.

Zigler, B. (2017, Dec. 20th). A Look Back At ETFs From The Trenches. Retrieved on March 30th 2020, from https://seekingalpha.com/article/4133027-look-back-etfs-from-trenches. 